\title{
Chemical Compounds and Antibacterial Activity of Tephrosia toxicaria Pers
}

\author{
A. M. CAMPOS ARRIAGA ${ }^{1 *}$, F. R. LOPES DA SILVA ${ }^{1}$, M. V. SOUSA TEXEIRA ${ }^{1}$, I. G. \\ PEREIRA ${ }^{1}$, M. R. DA SILVA ${ }^{1}$, JAIR MAFEZOLI', G. M. PEREIRA SANTIAGO', \\ J. N. E. VASCONCELOS ${ }^{2}$, R. BRAZ-FILHO ${ }^{3}$, J. G. MARTINS DA COSTA ${ }^{4}$, \\ EDINARDO F. F. MATIAS ${ }^{4}$ and F. F. GALVAO RODRIGUES ${ }^{4}$
}

\author{
1'Departamento de Quimica Organica e Inorganica, Centro de Ciencias, Universidade \\ Federal do Ceara, CP 12.200, 60021-940, Fortaleza-CE, Brazil. \\ ${ }^{2}$ Instituto Federal de Educacao, Ciencia e Tecnologia do Ceara, Campus Tiangua, \\ Rodovia CE 187 sn, Aeroporto, 62320-000, Tiangua-CE, Brazil. \\ ${ }^{3}$ Laboratorio de Ciencias Quimicas, Universidade Estadual do Norte Fluminense \\ Darcy Ribeiro, 28013-602, Campos dos Goytacazes-RJ, Brazil. \\ ${ }^{4}$ Universidade Regional do Cariri, Laboratorio de Pesquisas de Produtos Naturais, \\ Rua Cel. Antonio Luis 1161, 63105-000, Crato-CE, Brazil. \\ ${ }^{*}$ Corresponding author E-mail: ang @ufc.br \\ http://dx.doi.org/10.13005/ojc/330504
}

(Received: June 20, 2017; Accepted: July 30, 2017)

\section{ABSTRACT}

\begin{abstract}
Eight known compounds were isolated from the shrub Tephrosia toxicaria. Among them, 6,7-dimethoxy-chromone (1), was described by the first time from this genus, villosinol (2), which had been previously reported without its ${ }^{13} \mathrm{C}-\mathrm{NMR}$ data and sumatrol (3), which has its ${ }^{13} \mathrm{C}-\mathrm{NMR}$ data corrected. The antibacterial activity of Tephrosia toxicaria extract and obovatin (6), deguelin (7), 12a-hydroxy- $\alpha$-toxicarol (8), 12a-hydroxy-rotenone (10), and tephrosin (11) is also described.
\end{abstract}

Keywords: Tephrosia toxicaria, Flavonoids, ${ }^{13} \mathrm{C}$ NMR data, antibacterial activity.

\section{INTRODUCTION}

Tephrosia toxicaria Pers. (Fabaceae), also referred as T. sinapou (Buchoz), is a shrub popularly known as "timbo de caiena" in Ceara state (Northeast of Brazil) where it is used as pesticide and fishing poison ${ }^{1-2}$. The phytochemical studies of Tephrosia genus revealed compounds with anticinoceptive, larvicidal and antiinflammatory activities ${ }^{3,4}$. Previous investigations of $T$. toxicaria led to the identification of flavonoids, mainly rotenoids ${ }^{1-2,5-7}$. In the present work, we report the isolation of eight known compounds, including the chromone,(6,7)-dimethoxy-chromone,(1) described for the first time for this genus, the flavonoid, villosinol, (2) which has been previously reported 
without its ${ }^{13} \mathrm{C}$-NMR data and sumatrol, (3) which has its ${ }^{13} \mathrm{C}$-NMR data corrected. In addition, as a support of use of alternative source in the treatment of bacterial infections, we describe the antibacterial activity of ethanolic extract from its roots and of some its compounds.

\section{MATERIAL AND METHODS}

\section{Plant material}

Pods and roots of $T$. toxicaria Pers. were collected in Guaraciaba do Norte (Ceara state, Brazil). A voucher specimen (\#32139) is kept at the Herbarium Prisco Bezerra, Universidade Federal do Ceara - Brazil.

\section{METHODS}

The powdered pods, air-dried (180.0 g), were extracted with $95 \% \mathrm{EtOH}$ at and provided the extract TTVE (26.0 g). An aliquot (8.7 g) of TTVE was fractionated by silicon gel column (Merck 60-120 60 Mesh) using hexane, $\mathrm{CH}_{2} \mathrm{Cl}_{2}$ and EtOAc as solvents. The fraction eluted with $\mathrm{CH}_{2} \mathrm{Cl}_{2}(69.0 \mathrm{mg})$ furnished, after further silicon gel column, $6.7 \mathrm{mg}$ of $6 a, 12 a-d e s y d r o-\alpha$-toxicarol ${ }^{8}, 4$. The fraction eluted with EtOAc $(800.0 \mathrm{mg})$ was purified by Si gel column, furnished $19.9 \mathrm{mg}$ of luteolin ${ }^{9}, 5$. The powdered roots $(500.0 \mathrm{~g})$ were extracted with ethanol to afford TTRE (14.2 g). TTRE was chromatographed on a silicon gel column with gradient mixture of hexane $/ \mathrm{CH}_{2} \mathrm{Cl}_{2}$. Fractions eluted with hexane $/ \mathrm{CH}_{2} \mathrm{Cl}_{2}$ (1:1) yielded $13.2 \mathrm{mg}$ of obovatin ${ }^{10}, 6$, and the fractions eluted with $\mathrm{CH}_{2} \mathrm{Cl}_{2}$ furnished $9.9 \mathrm{mg}$ of deguelin 8 , 7. Another portion of roots $(649.0 \mathrm{~g})$ was extracted in a Soxhlet system with water. After liophilization, the material (5.4 g) was extracted with ethyl acetate and yielded $2.1 \mathrm{~g}$ of organic fraction. This fraction was chromatographed on Sephadex LH-20 using EtOAc:MeOH (1:1). The fractions obtained were submitted to HPLC RP-18 (MeOH/formic acid $0.1 \%$ $4: 1)$ and provided pure compounds villosinol ${ }^{11}(2$, $5.0 \mathrm{~m} \mathrm{~g}), 12 \mathrm{a}$-hydroxy- $\alpha$-toxicarol ${ }^{8}(8,32.8 \mathrm{mg})$, sumatrol $^{12}(3,3.6 \mathrm{mg}), \alpha$-toxicarol ${ }^{8}(9,13.0 \mathrm{mg}), 12 \mathrm{a}$ hydroxyrotenone ${ }^{13}(10,27.8 \mathrm{mg})$, tephrosin ${ }^{14}(11$, $62.0 \mathrm{mg}$ ), and 6,7-dimethoxy-chromone ${ }^{15}(1,2.0 \mathrm{mg})$. All compounds were identified by ${ }^{1} \mathrm{H}-\mathrm{NMR},{ }^{13} \mathrm{C}$ NMR and 2D NMR analysis and comparison with those reported in the literature.

\section{Antibacterial activity}

\section{Microorganisms}

The following strains used in this study were provided by the Oswaldo Cruz Foundation -FIOCRUZ: K. pneumoniae ATCC 10031; P. aeruginosa ATCC 15442; S. mutans ATCC 0046; $S$. aureus ATCC 6538. Strains isolated from clinical material of Escherichia coli 27 and Staphylococcus aureus 358 were also used. The bacteria were activated in Brain Heart Infusion (BHI, Himedia laboratories Pvt. Ltd., Mumbai, India) for $24 \mathrm{~h}$ at $35^{\circ} \mathrm{C}$.

\section{Antibacterial test (MIC) and resistance modulation bacterial}

MIC (minimal inhibitory concentration) was determined in a microdilution assay ${ }^{16}$ utilizing an inoculum of $100 \mu \mathrm{l}$ of each strain, suspended in $\mathrm{BHI}$ broth up to a final concentration of $10^{5} \mathrm{CFU} / \mathrm{ml}$ in 96-well microtiter plates, using serial dilutions (1:1). Each well received $100 \mu \mathrm{l}$ of each (roots ethanolic extract (TTRE) and of the compounds 6 , $7,8,10$ and 11). The concentrations of the extract and organic compounds varied $512-8 \mu \mathrm{g} / \mathrm{ml}$. MICs were recorded as the lowest concentrations required to inhibit growth.

The minimum inhibitory concentration for antibiotics was determined in $\mathrm{BHI}$ by the microdilution test, using suspensions of $10^{5} \mathrm{CFU} /$ $\mathrm{mL}$ and a drug concentration ranging from 2,500 to $2,4 \mu \mathrm{g} / \mathrm{ml}$ ( $1: 1$ serial dilutions). MIC was defined as a lower concentration at which growth was observed. For evaluation of the absence and presence of deguelin (7) and 12a-hydroxy- $\alpha$-toxicarol (8) in $P$. aeruginosa and Staphylococcus aureus modulators of antibiotic resistance, a MIC of the antibiotics was determined in the presence or absence of subunits and as plates were incubated for $24 \mathrm{~h}$ at $37^{\circ} \mathrm{C}$. Each antibacterial test for MIC determination was performed in triplicate.

\section{RESULTS AND DISCUSSION}

It is worth to mention that villosinol, 2 has its ${ }^{13} \mathrm{C}-\mathrm{NMR}$ data being reported for the first time, and that the ${ }^{13} \mathrm{C}$-NMR assignment for sumatrol, 3 was corrected through bidimensional NMR analysis. 
Villosinol (2). $\mathrm{C}_{23} \mathrm{H}_{22} \mathrm{O}_{8},{ }^{1} \mathrm{H}-\mathrm{NMR}\left(500 \mathrm{MHz}, \mathrm{CDCl}_{3}\right.$ ) $\delta_{H}: 1.74\left(\mathrm{~s}, 3 \mathrm{H}, \mathrm{CH}_{3}-8^{\prime}\right), 2.84$ (dd, $J=15.0$ and 7.5 $\mathrm{Hz}, 1 \mathrm{H}, \mathrm{H}-4$ 'a), 3.20 (dd, $J=15.0$ and $9.5 \mathrm{~Hz}, 1 \mathrm{H}, \mathrm{H}-$ 4'b), 3.76 (s, 3H, 2- $\left.\mathrm{OCH}_{3}\right), 3.83\left(\mathrm{~s}, 3 \mathrm{H}, 3-\mathrm{OCH}_{3}\right)$, 4.18 (s, 1H, 12a-OH), 4.47 (d, J=12.0 Hz, 1H, $\mathrm{H}_{\mathrm{eq}}{ }^{-}$ 6), 4.55 (sl, 1H, H-6a), 4.58 (dd, $J=12.0$ and 2.5 $\left.\mathrm{Hz}, 1 \mathrm{H}, \mathrm{H}_{\mathrm{ax}}-6\right), 4.93$ (s, 1H, H-7'), 5.05 (s, 1H, H-7'), 5.20 (t, J=8.5 Hz, 1H, H-5'), 6.04 (s, 1H, H-10), 6.49 (s, 1H, H-4), 6.71 (s, 1H, H-1), 11.83 (s, $1 \mathrm{H}$, 11-OH). ${ }^{13} \mathrm{C}-\mathrm{NMR}\left(125 \mathrm{MHz}, \mathrm{CDCl}_{3}\right) \delta_{\mathrm{C}}: 194.4$ (C12), 170.4 (C-9), 166.1 (C-11), 156.1 (C-7a), 151.6 (C-3), 148.7 (C-4a), 144.4 (C-2), 143.1 (C-6'), 113.2 (C-7'), 109.7 (C-1), 109.0 (C-1a), 105.0 (C-8), 101.4 (C-4), 100.2 (C-11a), 92.5 (C-10), 88.7 (C-5'), 75.8 (C-6a), 67.1 (C-12a), 63.9 (C-6), $56.7\left(2-\mathrm{OCH}_{3}\right)$, $56.2\left(3-\mathrm{OCH}_{3}\right), 30.8\left(\mathrm{C}-4\right.$ '), $17.3\left(\mathrm{C}-8^{\prime}\right)$.
Sumatrol (3). $\mathrm{C}_{23} \mathrm{H}_{22} \mathrm{O}_{7} \cdot \mathrm{mp} 213.6-215.1^{\circ} \mathrm{C} .{ }^{1} \mathrm{H}-\mathrm{NMR}$ (500 MHz, CDC13) $\delta_{\mathrm{H}^{\prime}}: 1.75$ (s, 3H, $\left.\mathrm{CH}_{3}-8^{\prime}\right), 2.86$ (dd, $J=15.0$ and $8.0 \mathrm{~Hz}, 1 \mathrm{H}, \mathrm{H}-4$ 'a), 3.24 (dd, $J=$ 15.0 and $9.5 \mathrm{~Hz}, 1 \mathrm{H}, \mathrm{H}-4$ 'b), 3.79 (s, 3H, 2- $\mathrm{OCH}_{3}$ ), $3.82\left(\mathrm{~s}, 3 \mathrm{H}, 3-\mathrm{OCH}_{3}\right), 3.85(\mathrm{~d}, J=4.0 \mathrm{~Hz}, 1 \mathrm{H}, \mathrm{H}-$ 12a), 4.17 (d, $J=12.0 \mathrm{~Hz}, 1 \mathrm{H}$, Heq-6), 4.59 (dd, $J=$ 12.0 and $3.0 \mathrm{~Hz}, 1 \mathrm{H}, \operatorname{Hax}-6), 4.88(\mathrm{t}, J=3.0 \mathrm{~Hz}, 1 \mathrm{H}$, H-6a), 4.93 (s, 1H, H-7'), 5.06 (s, 1H, H-7'), 5.20 (t, $1 \mathrm{H}, J=8.5 \mathrm{~Hz}, 1 \mathrm{H}, \mathrm{H}-5$ '), 6.02 (s, 1H, H-10), 6.46 (s, $1 \mathrm{H}, \mathrm{H}-4), 6.87$ (s, 1H, H-1), 12.42 (s, 1H, 11-OH). ${ }^{13} \mathrm{C}-\mathrm{NMR}(125 \mathrm{MHz}, \mathrm{CDC13}) \delta_{\mathrm{C}}: 193.8$ (s, C-12), 169.6 (s, C-9), 166.4 (s, C-11), 156.5 (s, C-7a), 150.1 (s, C-3), 147.6 (s, C-4a), 144.4 (s, C-2), 143.2 (s, C-6'), 112.8 (t, C-7'), 110.9 (d, C-1), 105.0 (s, C1a), 104.3 (s, C-8), 101.5 (s, C-11a), 101.4 (d, C-4), 92.1 (d, C-10), 88.4 (d, C-5'), 72.0 (d, C-6a), 66.3 (t, C-6), 56.7 (q, 2-OCH3), 56.2 (q, 3-OCH3), 44,0 (d, C-12a), 30.9 (t, C-4'), 17.3 (q, C-8').

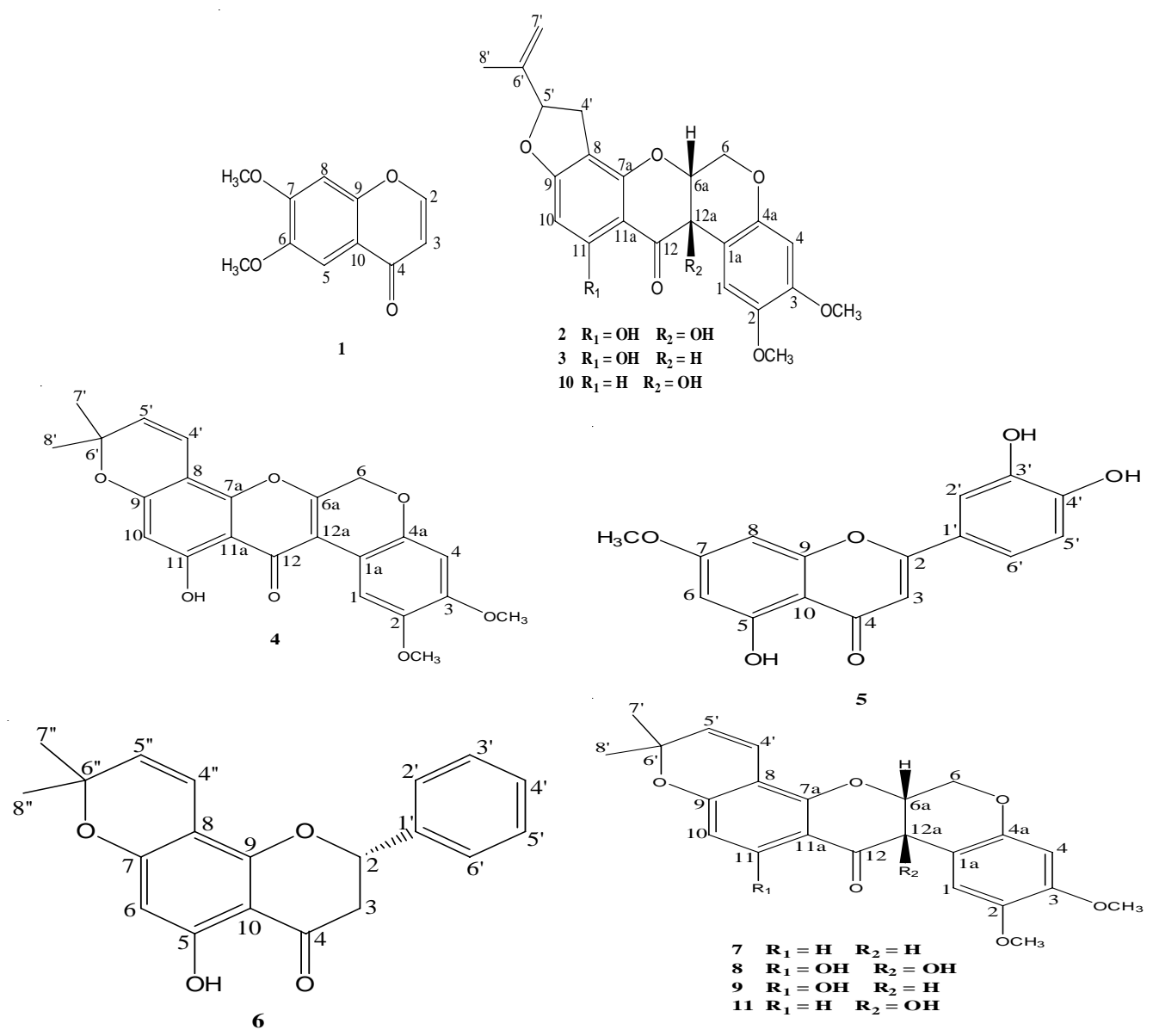

Fig. 1. Compounds isolated from T. toxicaria. 


\section{In vitro antibacterial activity}

The MICs of Tephrosia toxicaria extract, TTRE, obovatin, (6), deguelin (7), 12a-hydroxy- $\alpha$ toxicarol (8), 12a-hydroxy-rotenone (10), and tephrosin (11) against six bacterial strains are presented in Table 1. All tested compounds and extract showed antimicrobial activity against Grampositive and Gram-negative bacteria, with the best effect of $12 a$-hydroxy- $\alpha$-toxicarol against to the grown of Gram-positive S. aureus 358 with MIC 256 $\mu \mathrm{g} / \mathrm{mL}$, while Deguelin is responsible for the best result, the Gram-negative bacteria, $P$. aeruginosa was inhibited at $64 \mu \mathrm{g} / \mathrm{ml}$.

Table 2 shows the results concerning the modulation tests of bacterial resistance to aminoglycosides. When (7) and (8) compounds are combined with the antibiotic amikacin, tested against $P$. aeruginosa and $S$. aureus strains, the isolated and combined MIC values were the same. Synergism was observed in the combinations of (7) with gentamicin against the two bacterial strains used in the test and in the combination of (7) with neomycin against $P$. aeruginosa, characterized by reduction of MIC by $50 \%$ compared to MIC of the antibiotics tested alone. Only the (8) combination with neomycin against $S$. aureus showed antagonism, increasing the MIC by $50 \%$ compared to the MIC of the neomycin tested alone.

Some natural products of origin plant and phytochemicals are known to have antimicrobial properties, which may be of great importance in treatment against infections. With the increased incidence of antibiotic resistance, alternative natural plant products may be of interest ${ }^{17}$. Several studies have been conducted in different countries, demonstrating the efficacy of this type of treatment. Many natural products of plants were evaluated not only for direct antimicrobial activity, but also as resistance modifying agents ${ }^{18,19}$.

Various chemical compounds (synthetic or natural) have direct antibacterial activity against many species, expanding the activity of an antibiotic, reversing the natural resistance of bacteria to specific antibiotics, causing the inhibiting the active efflux of antibiotics through the plasma membrane and / or elimination of plasmids. Potentiation of antibiotic activity or reversion of resistance to antibiotics allows the classification of these compounds as modifiers of antibiotic activity ${ }^{20,21}$.

The mechanism described as "synergistic multi-effect targeting" or "Herbal shotgun" is a possible strategy that explains modulatory effects and refers to the use of plants and drugs in an approach using various-substance combinations, which may not only affect a single target, but several ones, where the different therapeutic components contribute in a synergistic-agonistic effect. This approach is not only for combinations of extracts: Combinations between complex mixtures (extracts and/or oil) and compounds chemical isolated synthetic or naturals or antibiotics are also possible ${ }^{22,23}$.

Table. 1: Values of the minimal inhibitory concentration (MIC) $(\mu \mathrm{g} / \mathrm{ml})$ of Tephrosia toxicaria extract and obovatin (6), deguelin (7), 12a-hydroxy- $\alpha$-toxicarol (8), 12a-hydroxy-rotenone (10), and tephrosin (11)

\begin{tabular}{lcccccc}
\hline & $\begin{array}{c}\text { E. coli } \\
(\mathbf{2 7})\end{array}$ & $\begin{array}{c}\text { K. pneumoniae } \\
\mathbf{( 1 0 0 3 1 )}\end{array}$ & $\begin{array}{c}\text { P. aeruginosa } \\
\mathbf{( 1 5 4 4 2 )}\end{array}$ & $\begin{array}{c}\text { S. mutans } \\
\mathbf{( 0 0 4 6 )}\end{array}$ & $\begin{array}{c}\text { S. aureus } \\
\mathbf{( 6 5 3 8 )}\end{array}$ & $\begin{array}{c}\text { S. aureus } \\
\mathbf{( 3 5 8 )}\end{array}$ \\
\hline $\mathrm{TTRE}$ & 512 & 512 & $\geq 1024$ & 512 & 512 & $\geq 1024$ \\
6 & $\geq 1024$ & $\geq 1024$ & $\geq 1024$ & 512 & 512 & $\geq 1024$ \\
7 & $\geq 1024$ & 512 & 64 & $\geq 1024$ & 512 & 512 \\
8 & 512 & 512 & $\geq 1024$ & $\geq 1024$ & 512 & 256 \\
10 & 512 & 512 & 512 & 512 & 512 & $\geq 1024$ \\
11 & 512 & 512 & 512 & $\geq 1024$ & 512 & $\geq 1024$ \\
\hline
\end{tabular}


Table. 2: MIC values $(\mu \mathrm{g} / \mathrm{mL})$ of aminoglycosides in the absence and presence of compounds (7) and (8) in P. aeruginosa and Staphylococcus aureus.

\begin{tabular}{lcccc}
\hline Antibiotics & \multicolumn{2}{c}{ P. aeruginosa (15442) } & \multicolumn{2}{c}{ S. aureus (358) } \\
\cline { 2 - 5 } & $\begin{array}{c}\text { MIC } \\
\text { alone }\end{array}$ & $\begin{array}{c}\text { MIC } \\
\text { combined (7) }\end{array}$ & $\begin{array}{c}\text { MIC } \\
\text { alone }\end{array}$ & $\begin{array}{c}\text { MIC } \\
\text { combined (8) }\end{array}$ \\
\hline Gentamicin & 64 & 32 & 64 & 32 \\
Amicacin & 32 & 32 & 64 & 64 \\
Neomycin & 32 & 16 & 32 & 64 \\
\hline
\end{tabular}

\section{CONCLUSION}

In conclusion, the prospective healthpromoting effects of plant secondary metabolites have encouraged the research about their chemical constitution and their potential to treat several diseases, among them bacterial infection. The plant substances and their extracts display rarely toxic side effects when compared in treatments with conventional drugs, so these results could be leads for the development of new antibacterial agent, or the compounds from $T$. toxicaria even may be used associates with standard antibiotics.
FRLS, MVST, JNV, JQL (Master and PhD sudents), IGP (Graduate student) contributed running the laboratory work and drafted the paper; AMCA, JM, MRS, RBF, GMPS did the analysis and interpretation of data of RMN, critical revision of the manuscript. JGMC, EFFM and FFGR contributed with the microbiological tests.

\section{ACKNOWLEDGEMENT}

The authors are grateful to CNPq, CNPq/ Pronex and CAPES for financial support and fellowships.

\section{REFERENCES}

1. Vasconcelos, J. N.; Lima, J. Q.; Lemos, T. L. G.; Oliveira, M. C. F.; Almeida, M. M. B.; Andrade-Neto, M.; Mafezoli, J.; Arriaga, A. M. C.; Santiago, G. M. P.; Braz-Filho, R. Quim. Nova, 2009, 32, 382-386

2. Vasconcelos, J. N.; Santiago, G. M. P.; Lima, J. Q.; Mafezoli, J.; Lemos, T. L. G.; Silva, F. R. L.; Lima, M. A. S.; Pimenta, A. T. A.; Braz-Filho, R.; Arriaga, A. M. C.; Cesarin-Sobrinho, D. Quim Nova, 2012, 35, 1097-1100

3. Chen, Y.; Yan, T.; Gao, C.; Cao, W.; Huang, R. Molecules, 2014,19, 1432-1458

4. do Val, D. R.; Bezerra, M. M.; Silva, A. A. R.; Pereira, K. M. A.; Rios, L. C.; Lemos, J. C.; Arriaga, N. C.; Vasconcelos, J. N.; Benevides, N. M. B.; Pinto, V. P.T.; Cristino-Filho, G.; Brito, G. A. C.; Silva, F. R. L.; Santiago, G. M. P.; Arriaga, A. M. C.; Chaves, H. V. European Journal of Pain, 2014, 18, 1280-1289
151-156

6. Arriaga, A. M. C.; Malcher, G. T.; Lima, J. Q.; Magalhães, F. E. A.; Gomes, T. M. B. M.; Oliveira, M. C. F.; Andrade-Neto, M.; Mafezoli, J.; Santiago, G. M. P. J. Essent. Oil Res. 2008, 20, $450-451$

7. Arriaga, A. M. C.; Lima, J. Q.; Vasconcelos, J. N.; Oliveira, M. C. F.; Andrade-Neto, M.; Santiago, G. M. P.; Uchoa, D. E. A.; Malcher, G. T.; Mafezoli, J.; Braz-Filho, R. Magnetic Resonance in Chemistry, 2008, 47, 537-540

8. Andrei, C. C.; Vieira, P. C.; Fernandes, J. B.; da Silva, M. F. G. F.; Rodrigues Filho, E. Phytomchemistry, 1997, 46, 1081-1085

9. Agrawal, P. K. Carbon-13 NMR of flavonoids; (Elsevier), 1989

10. Andrei, C. C.; Ferreira, D. T.; Faccione, M.; de Moraes, L. A. B.; de Carvalho, M. G.; BrazFilho, R. Phytochemistry, 2000, 55, 799-804

11. Krupadanam, G. L. D.; Sarma, P. N.; Srimannarayana, G.; Subbaroa, N. V. 
Tetrahedron Lett., 1977, 24, 2125-2128

12. Jang, D. S.; Park, E.J.; Kang, Y.; Hawthorne, M.E.; Vigo, J.S.; Graham, J.G.; Cabieses, F.; Fong, H.H. S.; Mehta, R. G.; Pezzuto, J. M. ; Kinghorn,A.D.; J. Nat. Prod., 2003 , 66, 1166-1170

13. Phrutivorapongkul,A.; Lipipun, V.; Ruangrunngsi, N.; Watanabe, T.; Ishikawa, T. Chem. Pharm. Bull., 2002, 50, 534-537

14. Ahmad, V. U.; Ali, Z.; Hussauni, S. R.; Iqbal, F.; Zahid, M.; Abbas, M.; Saba, N. Phytochemical Commun., 1999, 70, 443-445

15. Romussi, G.; Ciarallo, G. J. Heterocyclic Chem., 1976, 13, 211-220

16. Javadpour, M. M.; Juban, M. M.; Jo, W. C.; Bishop, S. M.; Alberty, J. B.; Cowell, S. M.; Becker, C. L.; McLaughlin, M. L. J. Med. Chem., 1996, 39, 3107-3113.

17. Matias, E. F. F.; Santos, K. K. A.; Almeida, T. S.; Costa, J. G. M.; Coutinho, H. D. M. Rev. Bras. Biocienc. 2010, 8, 294-298.
18. Matias, E. F. F.; Alves, E. F.; Santos, B. S.; Souza, C.E.S.;Ferreira,J.V.A.; Lavor, A. K. L.S.; Figueredo, F. G.; Lima, L. F.; Santos, F. A. V.; Peixoto, F. S. N.; Colares, A. V.; Boligon, A. A.; Saraiva, R. A.; Athayde, M. L.; Rocha, J. B. T.; Menezes, I. R. A.; Coutinho, H. D. M.; Costa, J. G. M. J. Evid. Based. Complementary Altern. Med., 2013a, 1-7

19. Matias, E. F. F.; Santos, K. K. A.; Falcão-Silva, V. S.; Siqueira-Junior, J. P.; Costa, J. G. M.; Coutinho, H. D. M. Indian J. Med. Res., 2013, 137, 178-182.

20. Coutinho, H. D. M.; Costa, J. G. M.; Lima, E. O.; Falcao-Silva, V. S.; Siqueira-Junior, J. P. BMC Complement. Altern. Med. 2009, 9, 13.

21. Coutinho, H. D. M.; Costa, J. G. M.; Lima, E. O.; Siqueira-Júnior, J. P. Comp. Immunol. Microbiol. Infect. Dis., 2010, 33, 467-471.

22. Hemaiswarya, S. H.; Kruthiventi, A. K.; Doble, M. Phytomedicine, 2008, 15, 639-652.

23. Wagner, H.; Ulrich-Merzenich, G. Phytomedicine, 2009, 16, 97-110. 